\title{
Archaeology and Autonomies: The Legal Framework of Heritage Management in a New Bolivia
}

\author{
Donna Yates*
}

\begin{abstract}
The 2009 Bolivian Constitution significantly changed the structure of the state and paved the way for the creation of regional, local, and even indigenous autonomies. These autonomies are charged with the management of archaeological sites and museums within their territory. This article answers the question of who currently owns the Bolivian past, it stems from concerns raised at the 2011 renewal hearing of the Memorandum of Understanding preventing the import of illicit Bolivian antiquities into the United States. By combining an analysis of recent legal changes related to the creation of the autonomies and a short discussion of a notable case study of local management of a Bolivian archaeological site, this article offers a basic summary of the legal framework in which Bolivian archaeology and heritage management functions and some preliminary recommendations for governments and professionals wishing to work with Bolivian authorities at the state and local level.
\end{abstract}

\section{BACKGROUND}

On 27 June 2011, the U.S. Department of State's Cultural Property Advisory Committee $^{1}$ met to discuss a five-year extension of the bilateral agreement between the United States and Bolivia, which bars the import of illicit Bolivian archaeological, ecclesiastical, and ethnographic material into the United States. ${ }^{2}$ The agreement, referred to as a Memorandum of Understanding (MOU), has been in place since

ॠDepartment of Archaeology, University of Cambridge. Email: dey21@cam.ac.uk

ACKNOWLEDGEMENTS: I would like to thank Professor Clark Erickson, Professor Sonia Alconini, and the members of the United States State Department Cultural Property Advisory Committee for providing me with the opportunity to focus my thoughts on this issue. I would also like to thank the anonymous reviewers of this article for their feedback and the editor for his encouragement. 
2001 and is seen as a positive step towards both combating antiquities trafficking and improving often-strained U.S.-Bolivia relations. ${ }^{3}$

The agreement is based on mutual commitment: The United States pledges to, essentially, enforce Bolivian export law by preventing various classes of object from entering its borders and Bolivia, in turn, pledges to devote significant time and effort into preventing those items from leaving the country in the first place. ${ }^{4}$ The extension of this and any other MOU related to antiquities trafficking prevention rests on several factors. First, the MOU must still be necessary. A similar MOU with Canada was allowed to expire in 2002 because sufficient evidence indicated that the state in question had antiquities trafficking under control. ${ }^{5}$ Second, the bilateral agreement must be effective. It takes time, money, and effort to enforce foreign export law at U.S. borders. If the antiquities-exporting country is unwilling or unable to improve the looting situation on the ground, or if absolutely no improvement is made despite considerable effort, the MOU will not be renewed.

The 27 June 2011 meeting differed from the previous Bolivian MOU extension in 2006 in that the United States is now negotiating with a new Bolivia. With the introduction of a new state constitution in 2009, the former Republic of Bolivia was reborn as the Plurinational State of Bolivia. ${ }^{6}$ The most striking feature of the constitution is the creation of regional, local, and even indigenous autonomies, each with the ability to self-manage and self-regulate in unique and separate ways. ${ }^{7}$ The autonomies are now the basic components of a decentralized Bolivian state. The members of the Cultural Property Advisory Committee expressed both interest in this singular reorganization of a modern state and concern about Bolivian heritage management following autonomization. ${ }^{8}$ This question was raised: Can a state that is based on a decentralized model effectively protect the archaeological material within its borders?

In an effort to answer this complex question, this article discusses the development of Bolivian archaeological law leading up to and following the implementation of the 2009 constitution. It is possible that the current structure of Bolivian heritage management established by the law represents an intriguing new spin on modern heritage management. Bolivian communities, especially autonomous ones, are charged with taking an active role in their own local archaeological resources. And by doing so they maintain a sense of connection and vested interest that a centralized state-level management system cannot inspire. Yet the Bolivian state maintains ownership of all archaeological material, making it the sole body that must be negotiated with for international agreements related to archaeological heritage, such as the MOU, and it is the legal receiver of repatriated archaeological material. ${ }^{9}$ The state also maintains the sole responsibility for the establishment of best practices for heritage preservation within Bolivia and is given the power to intervene if autonomies violate these standards. With few comparable case studies in autonomous management of archaeological sites, it is difficult to gauge whether such a unique model is sustainable. In a developing country such as Bolivia, this localized style of site administration might be impossible. 
Whether or not these laws will be effectively implemented remains to be seen. What is clear is that public knowledge of Bolivian archaeological law, at least outside of Bolivia, is nearly nonexistent. The laws themselves are difficult to locate and impossible to interpret without a clear understanding of shifts in both Bolivian politics and archaeological practice. Heritage organizations and researchers that operate in Bolivia as well as foreign governments wishing to enter into formal agreements with that state are do so without access to Bolivia's archaeological legal framework. In an effort to combat this lack of information, the following section provides the basic background of Bolivian archaeological legislation leading up to the constitutional creation of local autonomies. ${ }^{10}$

\section{BOLIVIAN ARCHAEOLOGICAL LAW BEFORE THE 2009 CONSTITUTION}

\section{Early Archaeological Legislation}

Before the creation of the autonomies, Bolivian archaeological law was not substantially different from heritage legislation in other Latin American countries. ${ }^{11}$ The basic premise of the Bolivian government's right to regulate archaeological material was established in 1906 when the National Congress passed a law that named the Bolivian nation as the rightful owners of the ruins of Tiwanaku, the ruins of the islands of Lake Titicaca, and all other ruins from the Inka period and before. ${ }^{12}$ This claim of ownership serves as the basic foundation of all subsequent Bolivian archaeological legislation. In this same early law, the exportation of objects from Bolivian archaeological sites is prohibited, ${ }^{13}$ and a 1909 decree clarifies the portion of the penal code under which antiquities smugglers are to be prosecuted. ${ }^{14}$ This decree also declares that government permits are required for all archaeological excavations within the country. Furthermore, in 1938 national ownership of all Bolivian archaeological material was formalized in the political constitution of the state, which also reinforced the prohibition on exportation of these objects. $^{15}$

Other early Bolivian archaeological laws tackle what seems to have been the continuing problem of archaeological site looting and antiquities smuggling. For example, a 1939 law set standards for a newly created General Directorate of Tourism and specifically charges this body with preventing tourists from removing artifacts from the country. ${ }^{16}$ Also, a law passed in 1948 compelled farmers and road construction workers operating near the site of Tiwanaku to turn over objects that they found incidentally to the local museum. ${ }^{17}$ During this time the national monument scheme was established, ${ }^{18}$ the site of Tiwanaku was declared to be a national monument, ${ }^{19}$ and the national archaeology museum in La Paz was founded. ${ }^{20}$ 


\section{Professionalized and Nationalized Archaeology}

Following the 1952 National Revolution and subsequent social reforms, archaeology took center stage in Bolivia, with the ancient past serving as a tool of validation for the new government. Under the control of archaeologist Carlos Ponce Sanginés, Bolivian archaeology was both modernized and nationalized. ${ }^{21}$ Ponce's archaeological scheme was undoubtedly nationalistic: The past was used to validate the state and establish a particular idea of Bolivianness. ${ }^{22}$ Several laws and regulatory documents from the period reflect this use of archaeology. A 1958 Ministry of Education and Fine Arts resolution both formally structured the way archaeology was to be conducted in the country and imposed a closed-door policy on foreign archaeological researchers working in Bolivia. ${ }^{23}$ In theory, foreign archaeologists were allowed to conduct excavations in Bolivia provided they jump through a variety of hoops that were not required of Bolivians. These included the submission of aerial photographs of all sites that they wished to excavate, ${ }^{24}$ the donation of 50 copies of any publication that resulted from Bolivian excavations, ${ }^{25}$ and a promise to "protect the interests of the [Bolivian] State" through the work they conduct. ${ }^{26}$ In practice, Bolivian archaeology was to be performed by Bolivians. This archaeological isolationism would last for nearly two decades.

One significant addition to Bolivia's heritage management system at this time was a 1961 Ministry of Education resolution that implemented a national registry for all archaeological objects held both publically and privately in Bolivia. ${ }^{27}$ This resolution was formalized in the 1967 state constitution, which required the Bolivian state to keep a registry of all archaeological objects within its jurisdiction as well as to allot funds to preserve these objects. ${ }^{28}$ Two decrees expanded upon this national registry of "cultural treasures of the nation" in 1975. The first created the Instituto Nacional de Arqueología, which was put under the directorship of Carlos Ponce, ${ }^{29}$ and the second gave this organization the responsibility of managing the constitutionally mandated antiquities registry. ${ }^{30}$

By the 1970s, aspects of Bolivian law regarding the ownership of archaeological material were a bit opaque. Bolivian artifacts could (and still can) be privately held but not privately owned. While an individual may be allowed to house an antiquity that has been entered into the national registry, the object remains the property of the nation and cannot legally be transferred or exported. In an attempt to further clarify the ownership of cultural property, a 1978 legal decree closed what could be seen as a legal loophole. While the 1967 constitution stated that private property could not be expropriated by the state, ${ }^{31}$ the same constitution stated that archaeological objects were cultural treasures of the nation and were, thus, owned by the nation. ${ }^{32}$ The question was this: Could archaeological objects resting in private hands be expropriated? The 1978 decree reinforced the original 1906 claim of state ownership over archaeological material and clarifies that cultural treasure in private hands within Bolivia that is either unregistered or not being taken care of is a special class of object that is subject to state appropriation. ${ }^{33}$ 


\section{0s Privatization and 1990s Internationalism}

Starting in the mid-1970s and throughout the 1980s foreign archaeologists were again allowed to work in Bolivia. This was facilitated by a general shift in the focus of Bolivian politics following the fall of both the revolutionary governments of the 1950s and 1960s and the dictatorships and ruling juntas of the 1970s. In the mid-1980s, Bolivia adopted the now-infamous New Economic Policy and became an often-cited case study in the use of neoliberal reform and privatization to combat hyperinflation. ${ }^{34}$ Archaeology was not a state priority at this time, and scant archaeological legislation was passed in Bolivia until the early 1990s. ${ }^{35}$

In the 1990s a more politically stable Bolivia began to participate heavily in international archaeological and heritage circles. ${ }^{36}$ In 1988, the Bolivian government requested that the United States place emergency import restrictions on textiles originally from the village of Coroma. ${ }^{37}$ These textiles, known as kepis, have religious significance for modern inhabitants of the village, and their export is clearly prohibited under Bolivian law. ${ }^{38}$ In 1989 the United States granted this request. $^{39}$ To support this agreement a decree was signed in 1990, which stated that textiles repatriated to Bolivia through the U.S. import restrictions were to be returned to their community of origin. ${ }^{40}$ This marks the first time that indigenous Bolivians are specifically mentioned in a piece of archaeological legislation. ${ }^{41}$ The success of these emergency restrictions played a large part in the approval of the previously mentioned 2001 MOU between the United States and Bolivia and the extension of that MOU in 2006. ${ }^{42}$

Also during the 1990s, the Bolivian government became interested in participation in UNESCO, and in 1991 the government referred Tiwanaku for inscription on the UNESCO World Heritage list. Tiwanaku's inclusion on the list was deferred twice: first immediately following nomination because the World Heritage Committee felt that the boundaries of the protected area were not clearly defined, and again in 1998 because not enough information was provided regarding the protection and management of the site. ${ }^{43}$ Meanwhile, the Bolivian site of Samaipata near Santa Cruz was inscribed on the World Heritage list in $1998 .{ }^{44}$ In response to the unfavorable UNESCO rulings regarding the protection plan for Tiwanaku, decrees were signed in 1998 and 2000 to address specific concerns. These decrees create the National Commission of Protection, Conservation and Management at Tiwanaku ${ }^{45}$ and establish a 100-meter-wide protected perimeter around the core area of the site. ${ }^{46}$ In November of 2000, Tiwanaku was finally inscribed on the UNESCO World Heritage List. ${ }^{47}$

Although seemingly unrelated to the practice of archaeology in Bolivia, a particularly notable constitutional change occurred during the 1990s. In 1994 the constitution was amended to describe the Republic of Bolivia as "multiethnic and pluricultural." 48 This can be seen as the antecedent to Bolivia's recent name change. ${ }^{49}$ 


\section{The "Goni" and Mesa Presidencies (2000 to 2005)}

The past decade has been both turbulent and defining for Bolivia. In 2001 President Hugo Banzer Suárez resigned from office, ostensibly because of lung cancer. However, political disaster in the form of a series of social upheavals known as the "Water Wars" no doubt sped his exit. ${ }^{50}$ In 2002 Gonzalo Sánchez de Lozada Bustamante, known as "Goni," was elected to his second term as president. ${ }^{51}$ During this national election, indigenous political groups commanded a substantial percentage of the voter share, and the party MAS (Movimiento al Socialism), fronted by Evo Morales, lost by less than 2\%. ${ }^{52}$ In 2003 the extended social conflicts surrounding the ownership and management of Bolivia's natural gas reserves, known as the "Gas Wars," came to a head with the violent suppression of indigenous blockades by the Bolivian military. This was a significant rallying point for Bolivia's indigenous majority, and the turmoil led to Sánchez de Lozada's resignation from the presidency in October of 2003. ${ }^{53}$ Carlos Mesa Gisbert, the sitting vice president, replaced Sánchez de Lozada. He too resigned from the presidency in June of 2005 because of indigenous criticism and public protest. ${ }^{54}$ The chief justice of the Supreme Court, Eduardo Rodríguez Veltzé, replaced Mesa as president after two other men in the line of succession declined the office. ${ }^{55} \mathrm{~A}$ general presidential election was then held in December of $2005 .^{56}$

An interesting outcome of the increased success of indigenous movements within Bolivia at this time was the transfer of the management of the site of Tiwanaku to the modern municipality of the same name in $2000 .{ }^{57}$ Yet the majority of archaeological legislation passed during Mesa's short time in office was focused on the expansion of archaeological tourism. Indeed, nine laws were passed in less than three years that delineated areas of interest for archaeological tourism, calling for public and private, national, and international investment in these areas. ${ }^{58}$ These laws represent a top-down, investment-centered idea of tourism development and it is unclear, because of the swiftness of Mesa's departure from office, if these were ever implemented.

\section{Early Morales Administration (2006 to 2009)}

The election of Evo Morales, who self-identifies as Aymara, as the 80th president of Bolivia was a singular and defining moment for the country. For the first time in Bolivia's turbulent history, an indigenous person was chosen to lead the country. Although Bolivia has always housed an indigenous majority population, ${ }^{59}$ it was only since the implementation of aspects of the 1994 Law of Popular Participation that indigenous communities were able to front electoral candidates for higher-level positions. ${ }^{60}$ Indeed, for most of Bolivia's existence, social norms and legal restrictions prevented indigenous people from taking part in Bolivian public life and the election of Morales represents the first true break from the white oligarchy that has ruled Bolivia since independence from Spain in 1825. Further- 
more, Morales commanded a full $53.7 \%$ of the popular vote, an outright majority normally unheard of in a Bolivian election. ${ }^{61}$ With the power of an outright majority of Bolivians behind him, Morales felt he had a mandate to substantially change Bolivia, shaping the country with both socialist and indigenous policies. He was re-elected in 2009 with an even larger outright majority, $63 \%$ of the vote. ${ }^{62}$

Before the 2009 constitution the Morales administration made no substantive change to archaeology or heritage legislation. Tourism development was a common theme in the archaeological laws passed during this period. However, instead of focusing on inspiring external investment like the Mesa administration did, Morales-period laws focus more on community-level or sustainable tourism, such as a decree signed in 2007 that envisions "participatory tourism" as facilitating "the equitable redistribution of economic surplus." 63 This change in tone can be seen as a precursor to the wording of the new constitution.

\section{Summary of Bolivian Archaeological Law (1906 to 2008)}

More than a century ago, the government of Bolivia declared that all archaeological remains, even those yet to be excavated, were the cultural property of the nation and, as such, could not be exported. Over the years this basic claim of ownership was reaffirmed by both legislation and constitutional amendment. Later on the government was charged with the maintenance of a registry of archaeological objects in both public and private hands, and this duty was eventually entrusted to the archaeological wing of the Ministry of Culture. By the 1990s Bolivia actively participated in international heritage protection efforts, enacting internal legislation that facilitated antiquities-related bilateral agreements with the United States and the inclusion of Bolivian sites on the UNESCO world heritage list. In the turbulent early 2000s, the Bolivian government shifted its focus to the development of archaeological tourism while experimenting with community management of the site of Tiwanaku. This focus on archaeological tourism development continued into the early Morales administration in the form of socalled sustainable tourism.

What is absent in this summary is a discussion of the actual implementation of the laws discussed. While Bolivian heritage legislation is rarely contradictory, the stated goals of many of the laws passed in Bolivia from 1906 until the present are both lofty and expensive. As various recent archaeological scandals have shown, compliance with the law has often been poorly enforced. Legal decrees that mandate various types of development are easily forgotten following major governmental change. A complete account of the implementation of the back corpus of Bolivian law is outside of the scope of this article. The laws as passed, signed, and presented, then, represent an idealized framework: a snapshot of how the Bolivian government viewed archaeology and heritage at any given point in time. Realistic or not, the laws as written represent how archaeologists and foreign governments must approach Bolivia on the topic or heritage management. 


\section{ARCHAEOLOGY AND HERITAGE AFTER THE 2009 CONSTITUTION}

The new Bolivian constitution, which went into effect on 7 February $2009,{ }^{64}$ is a long and complex document. Through this constitution, the state is officially refounded, calling on ancient and indigenous claims of authenticity to validate massive changes to the nationalistic underpinnings of the country. ${ }^{65}$ The constitution mandates broad changes in the function of the central government. It creates the possibility of regional, municipal, and indigenous autonomies, ${ }^{66}$ which are given the right to a substantial degree of self-management. ${ }^{67}$ With the creation of the autonomies, Republican-era terminology is omitted and the country is formally renamed The Plurinational State of Bolivia. ${ }^{68}$ All indigenous languages are declared national languages, ${ }^{69}$ Catholicism is abandoned as the official state religion and freedom of religion is protected, ${ }^{70}$ and members of indigenous autonomies are granted the right to have their ethnic identity inscribed on their passport under the heading of nationality. ${ }^{71}$

Autonomized Bolivia, then, is an entirely new Bolivia, and the right to selfmanagement granted by the constitution includes a substantial role in the protection of archaeological heritage. Specifically, autonomous departmental governments are charged with the promotion and conservation of, among other things, department cultural and archaeological heritage. ${ }^{72}$ Autonomous municipal governments are charged with the promotion and conservation of municipal archaeological heritage. ${ }^{73}$ Finally, autonomous indigenous groups are charged with the safeguarding and promotion of their archaeological centers. ${ }^{74}$

\section{Is Autonomized Heritage Protectable Nationally and Internationally?}

The constitution makes it clear that the autonomies will be key players in the future of Bolivian heritage management. The question is, then, how autonomous are the autonomies when it comes to the protection of Bolivian archaeological sites and the prevention of illicit antiquities trafficking? How can the stipulations of such international agreements as the U.S.-Bolivia MOU be enacted and enforced in this model? Who exactly owns the Bolivian past? ${ }^{75}$

I believe that the matter has been significantly clarified by the so-called "Framework of autonomies and decentralization 'Andrés Ibáñez' law” passed in July of $2010 .^{76}$ A portion of this law is entirely devoted to the management of cultural heritage following departmental, municipal, and indigenous autonomization. ${ }^{77}$ The law creates a system of checks regarding the management of archaeological heritage at all levels and the central government retains the exclusive power to define policies for the protection, conservation, and preservation of cultural heritage. ${ }^{78}$ The government is charged with monitoring compliance with the archaeological and preservation standards that it sets. ${ }^{79}$ It is also charged with the upkeep of the 
formal registry of archaeological objects within the country. ${ }^{80}$ While the autonomies are given wide authority to develop local schemes for archaeological protection, recording, and conservation, the law clearly states that these local practices must all fall within the framework of state-level policies. ${ }^{81}$ In other words, autonomies are able to develop regionally specific solutions to their archaeological and heritage management problems but these solutions are subject to central government oversight. The government can and will intervene if their standards are violated. $^{82}$

An important aspect of this new structure of Bolivian heritage management is that one key policy has not changed. The Bolivian nation has not relinquished its claim on archaeological material, and so the Bolivian government is still the owner of all discovered and undiscovered Bolivian archaeological remains. The claim made in the Law of 3 Oct. (1906) (Bol.) still stands. While the autonomies are charged with managing archaeological sites and objects that fall within their jurisdictions, they do not own those objects. Taking this a step further, autonomies cannot sell archaeological objects or destroy archaeological sites, because they simply do not have the authority to do so. ${ }^{83}$ International agreements can still be made with the central Bolivian government regarding the protection of archaeological sites and the return of Bolivian artifacts because the central government retains ownership of this type of cultural property.

This form of local management of archaeological remains combined with creation of basic standards and continued centralized oversight may represent a positive new preservational structure for a developing country. Bolivia, with its turbulent political and social history, is the poorest and least developed country in South America. ${ }^{84}$ Routing all aspects of the management of archaeological sites through the central government of a poor state like Bolivia often leads both to regional inequalities in investment and to mismanagement due to lack of sitespecific protection plans. ${ }^{85}$ By allowing indigenous groups, municipalities, and regional governments to become the dominant force in localized site management and development schemes, local needs may finally be addressed. The very people who best understand the nuance of local threats to archaeological sites are charged with protecting and promoting the past in unique, site-specific ways. ${ }^{86}$ Also, these communities are positioned to benefit financially from the sites in their care: Revenue generated from archaeological tourism is retained for reinvestment in the community. If this works, other developing countries may wish to take note.

\section{CASE STUDY IN LOCAL SITE MANAGEMENT: TURBULENCE AT TIWANAKU}

The key phrase, of course, is "if this works." Recent events at the site of Tiwanaku signal that there may be significant points of friction stemming from local control 
of archaeological sites. As previously mentioned, the modern town of Tiwanaku, which is almost entirely composed of indigenous Aymara inhabitants, was granted some degree of control over the archaeological site in 2000. ${ }^{87}$ According to ethnographic work conducted by Clare Sammells, the actual division of power between the municipality and the central government stemming from the 2000 law was ambiguous. ${ }^{88}$ The national archaeology service and the Ministry of Culture were under the impression that the community would have control only of the tourism-related aspects of the site of Tiwanaku. The community was under the impression that, while they could not grant archaeological permits, they held veto power over both who could excavate at the site and where excavations could take place. ${ }^{89}$ Basically, the community believed that all activities at Tiwanaku, both archaeological and touristic, required their approval.

There was no significant challenge to this uncertain situation until July of 2009 when Eulogia Quispe, the mayor of the municipality of Tiwanaku, effectively fired a group of archaeologists from the national archaeological unit that were working at the site, citing inferior excavation techniques and questionable restoration work done on the site's main pyramid. ${ }^{90}$ The municipality then hired their own team of archaeologists to continue working at the site. These archaeologists were to be paid through a locally administered Venezuelan grant. ${ }^{91}$ The Ministry of Culture initially questioned whether the municipality had the legal ability to prevent a government archaeological project from continuing. ${ }^{92}$ Based on both the new constitution and the original 2000 law, the community of Tiwanaku felt that such actions were entirely within their rights as autonomous administrators of the archaeological site. ${ }^{93}$

As the extent of the problems at Tiwanaku became clear the Ministry of Culture came to support the termination of the archaeological project in question. ${ }^{94}$ Although the Ministry of Culture did not formally acknowledge that the municipality had the right to fire anyone, the Ministry itself fired the head of the national archaeological service, and the deputy minister of culture in charge of cultural heritage resigned. ${ }^{95}$ UNESCO sent several missions to assess damage caused by archaeological mismanagement of the site and, for a time, Tiwanaku seemed close to losing its World Heritage status. ${ }^{96}$ Instead, UNESCO opted to suspend grant payments to Tiwanaku until the site is brought into compliance with requirements set out by UNESCO experts. ${ }^{97}$ In the aftermath of this scandal, it has come to light that there may be some serious discrepancies in the formal registry of archaeological objects under state protection. ${ }^{98}$

Following these issues, questions as to who controls the site of Tiwanaku remain. In February of 2011, the Ministry of Culture created the Center for Archaeological and Anthropological Investigation and the Administration of Tiwanaku (Centro de Investigaciones Arqueológicas Antropológicas y Administración de Tiwanaku or CIAAAT) with the aim of meeting the requirements set by UNESCO. ${ }^{99}$ In recognition of the stipulations laid out by the 2009 constitution and the new laws concerning the organization of autonomous governments, 
CIAAAT contains representatives from the Autonomous Departmental Government of La Paz, the Municipal Government of Tiwanaku, with some supervision from the central government through the Ministry of Culture. Through CIAAAT, the Tiwanaku municipality retains their legal right to manage the site in accordance with government-set base standards of practice. ${ }^{100}$ This does not sit well with some sectors of Bolivian society, particularly those who oppose the current regime. $^{101}$

\section{THOUGHTS AND RECOMMENDATIONS}

Although conflict related to local versus national control of the site of Tiwanaku has filled newspaper opinion pages for the past three years, the new model of autonomous management of local archaeological resources is not necessarily flawed. Indeed, Tiwanaku has always been the exception in Bolivian heritage management, not the rule. Tiwanaku is a political space that is symbolic of the Morales administration, is the most visited archaeological site in the country, and receives the most attention and funding because of its international fame and World Heritage status. ${ }^{102}$ There are financial, social, and political reasons to squabble over control of Tiwanaku. No other archaeological site in Bolivia is comparable to Tiwanaku and, indeed, no other archaeological site in Bolivia has the same problems.

Tiwanaku is the only Bolivian archaeological site that has been autonomously managed for a significant period of time, and it is the only case study available for consultation in the construction of autonomous management schemes for other Bolivian archaeological sites. Yet information gleaned about the management of such a unique site is difficult, if not impossible, to apply to other locations. With no clear rubric for the success or failure of this new management scheme, and without prior case studies suitable for comparison, observers of heritage management under the new system of autonomies are essentially flying blind. Autonomous local control of Bolivian archaeological sites may turn out to be a natural transition or it might create a legal and regulatory minefield.

All told, we are witnessing the creation of a new Bolivia. Although the final outcome of this experiment is unclear, archaeologists and heritage professionals need not wait on the sidelines for the dust to settle. It is in the protection of smaller, more remote, and more vulnerable sites that we will see the successes of management by local autonomies. By working directly with autonomous governments to develop professional and targeted development and protection plans, we may just see a flowering of creative solutions to local heritage management problems. Agencies and international bodies conducting antiquities-related negotiations with Bolivia at a governmental level might find that by placing emphasis on community stewardship and participation they may catch the current administration's interest. By focusing on these aspects of Bolivia's new administrative structure, it might be possible to craft substantive agreements that will have a lasting positive effect 
on archaeological site protection and the prevention of looting and antiquities trafficking in Bolivia.

\section{ENDNOTES}

1. Created via $\$ 306$ of the 1983 Convention on Cultural Property Implementation Act. It is composed of eleven members appointed to renewable three-year terms and includes two members who represent the interest of museums; three members who are experts in archaeology, ethnography, or related fields; three members who are experts in the sale of cultural property; and three members who represent the interests of the general public.

2. 76 FR 32010 (2 June 2011).

3. 66 FR 63490-63499 (7 December 2011); At the time of writing, the post of United States Ambassador to Bolivia remains vacant following the expulsion of Philip S. Goldberg in September of 2008. Goldberg was declared persona non grata by the Bolivian Government following accusations that he supported the political opponents of President Evo Morales and had attempted to destabilize the country. This incident was widely reported in the international press, for example, John Lyons, "Bolivia Expels American Ambassador," Wall Street Journal, 11 September 2008.

4. The United States, as a state party to the 1970 UNESCO Convention on the Means of Prohibiting and Preventing the Illicit Import, Export and Transfer of Ownership of Cultural Property, is allowed to consider requests from other states party to that convention to impose restrictions on the import of archaeological material provided that the looting of that material jeopardizes the cultural heritage of that nation. See Public Law 97-446 or 19 USC 2601 et seq for the particulars of U.S. implementation of the UNESCO convention. The United States has entered into similar MOUs with Cambodia, Canada (expired), China, Colombia, Cyprus, El Salvador, Greece, Guatemala, Honduras, Iraq (in the form of emergency import restrictions), Italy, Mali, Nicaragua, and Peru.

5. See Bureau of Educational and Cultural Affairs, Canada.

6. BOL. CONST. (2009) art. 1.

7. BOL. CONST. (2009) part III.

8. The author was present at this meeting.

9. Repatriation of cultural objects usually rests on the recognition of rightful ownership. If ownership of a cultural object is unclear, repatriation is difficult.

10. A more complete discussion of Bolivian archaeological law can be found in Yates, "Archaeological Practice and Political Change."

11. It is not unusual for Latin American states to claim ownership of all archaeological material, both discovered and undiscovered, within their territory. For example, see law 6634, art. 1 (1929) (Perú).

12. Law of 3 Oct. (1906) (Bol.); Tiwanaku, known at the time of this law by the Hispanized name Tiahuanaco, is a monumental site located about 70 miles west of La Paz and 15 miles from Lake Titicaca in the high Andean plain at more than 12,500 feet above sea level. It was the center of a major culture with a sphere of influence that included parts of coastal Chile and Perú from approximately AD 300 to $\mathrm{AD} 1000$. It is the most visible archaeological site in Bolivia and is a primary source of symbolic validation for Bolivian political and social movements. A modern indigenous village with foundations in the conquest era exists next to the site of Tiwanaku and shares the same name.

13. Thus the exportation of Bolivian antiquities has been illegal since 1906. Archaeological material that has left Bolivia since 1906 without the consent of the government has been taken from the country illegally.

14. Decreto Supremo [hereafter D.S.] of 11 Nov. (1909) (Bol.).

15. BOL. CONST. (1938) art. 163.

16. Decreto Ley [hereafter D.L.] of 24 Nov. (1939) (Bol.).

17. Law of 30 Dec. (1948) (Bol.).

18. Law of 6 Jan. (1919) (Bol.).

19. Law of the National Monument (1927) (Bol.); D.S. of 15 Apr. (1930) (Bol.).

20. Law of 25 Feb. (1945) (Bol.). 
21. See Ponce, Tiwanaku: 200 Años.

22. Ponce was actively involved in MNR, the political party associated with the 1952 revolution. Janusek has noted that, in Ponce's view, "all of significance in Bolivia's pre-Hispanic past was in some way linked to Tiwanaku state development or military-political control" (see Proyecto Arqueológico Jach'a Machaca, Khonkho Wankane). There was a purposeful conflation of the so-called "Tiwanaku state" with the postrevolutionary Bolivian state. Janusek, "Khonkho WanKane".

23. Res. Min. Educación y Bellas Artes of 6 Jan. (1958) (Bol.).

24. Res. Min. Educación y Bellas Artes of 6 Jan. (1958) art. 16. (Bol.).

25. Res. Min. Educación y Bellas Artes of 6 Jan. (1958) art. 45. (Bol.).

26. Res. Min. Educación y Bellas Artes of 6 Jan. (1958) art. 7, § a. (Bol.).

27. Res. Min. Educación 1642 (1961) (Bol.).

28. BOL. CONST. (1967) art. 191.

29. D.S. 12302. (1975) (Bol.); National Institute of Archaeology (INAR). This entity later became the National Directorate of Archaeology or DINAR, and later still the National Directorate of Archaeology and Anthropology or DINAAR.

30. D.S. 12638 (1975) (Bol.).

31. BOL. CONST. (1967) art. 22.

32. BOL. CONST. (1967) art. 191.

33. D.L. 15900.

34. D.S. 20160 (1985) (Bol.); repealed by D.S. 0861 (2011) (Bol.).

35. Although archaeology was not a government focus at the time, the practice and premise of Bolivian archaeology came under intense indigenous scrutiny in the 1980s. See Rivera, "La Antropología y Arqueología," and Mamani, "History and Prehistory."

36. Jaime Paz Zamora emerged as the winner of the 1989 Bolivian presidential election because of an unlikely coalition with political opponent and former dictator Hugo Banzer Suárez. This election is generally hailed as Bolivia's return to relatively stable democracy.

37. Coroma is a small indigenous Aymara village roughly located between the cities of Oruro and Potosí on the road that leads from Oruro to the Uyuni salt flats, a popular tourist destination.

38. At the very least, the ancient ones were according to both law of 3 Oct. (1906) (Bol.) and BOL. CONST. (1938) art. 163. It could be argued that kepis that were not ancient were not property of the nation and were not barred from export by those laws. However, if the modern kepis are not the cultural property of the nation, they are the private property of the village of Coroma and their removal and subsequent sale in the United States amounted to the trafficking of stolen goods. See Constance Lowenthal, "The Recovery of the Aymara Textiles: Textiles Returned," Wall Street Journal, 9 December 1992, and Sarah Booth Conroy, "Sacred Textiles Returned to Bolivia," Washington Post, 25 September 1992.

39. 54 FR 10618-10620 (14 March 1989).

40. D.S. 22546 (1990) (Bol.).

41. This is a marked change from prior Bolivian heritage legislation that would most likely have placed returned objects into the care of the national museum system.

42. 66 FR 63490-63499 (7 December 2001); 71 FR 69477-69478 (1 December 2006).

43. ICOMOS Advisory Body Evaluation No. 567 rev. 2000.

44. UNESCO 22COM VIIIB.1. Commonly called the Fort of Samaipata, this was most likely a religious center for an Arawak group called the Chané.

45. D.S. 25263 (1998) (Bol.).

46. D.S. 25647 (2000) (Bol.).

47. UNESCO 24COM XC.1. It is worth noting that a specific concern raised by UNESCO was that a substantial portion of Tiwanaku is inauthentic. In the 1960s and 1970s, substantial portions of the Kalasasaya temple were fancifully reconstructed to fit with Ponce's vision of the Tiwanaku state. These reconstructions are almost universally denounced. See Gasparini, "Mejor Conservar que Restaurar," for a scathing period critique of the reconstruction.

48. Law 1585, art 1 (1994) (Bol.).

49. BOL. CONST. (2009) art. 1. 
50. See Dangl, The Price of Fire, or Kohl and Farthing, Impasse in Bolivia, for accounts of recent Bolivian resource conflicts.

51. Before the 2009 constitution, Bolivian presidents could serve two terms of five years but these terms could not be sequential. See BOL. CONST. (1967 with reforms and amendments through 2005) art. 87. The longer presidential tenures and three-term presidents in Bolivia's history are the results of either dictatorships or technicalities. Following the 2009 constitution, a Bolivian president is limited to two five-year terms, and those terms may be sequential. See BOL. CONST. (2009) art. 156.

52. Van Cott, "From Exclusion to Inclusion."

53. Kohl, "Privatization Bolivian Style."

54. Albro, "The Culture of Democracy."

55. The two men in line for the presidency following the resignation of the former vice president were Hormando Vaca Díez, the president of the Senate, and Mario Cossío, the president of the Chamber of Deputies. Indigenous protesters considered both men to be partisan members of the white oligarchy, so they were essentially forced to give up their right to assume the presidency.

56. A constitutional mandate forced a general election to be called within a year of the chief justice assuming the office of the president. See 1967 Const Bol. art $93 \$$ III.

57. Law 2054 (2000) (Bol.).

58. Specifically laws 2527, 2533, 2562, 2580, and 2610 in 2003; D.S. 27607 in 2004; laws 2950, 2966 and 2980 in 2005.

59. Bolivian demographic information regarding the indigenous population is variable. The 2001 national census found Bolivia to be made up of roughly 30\% Quechua speakers, 25\% Aymara speakers, and $45 \%$ Spanish speakers. However, to say that Bolivia is 55\% indigenous excludes those who identify culturally as Aymara or Quechua but do not speak an indigenous language, such as President Morales himself, or people who chose to hide their indigenousness due to racial prejudice. Bolivia's National Institute of Statistics numbers the self-identifying indigenous population at $65 \%$, and it will be exciting to see the demographic figures from Bolivia's next national census.

60. Law 1551 (1994) (Bol.).

61. In 2005 there were eight official candidates running for the presidency. At the time, if no candidate commands an outright majority of the popular vote and if no coalition government is agreed upon, the National Congress of Bolivia would elect the president from the two candidates who received the most votes.

62. Carrol, Rory. "Evo Morales Wins Landslide Victory in Bolivian Presidential Elections," Guardian, 7 December 2009.

63. D.S. 2922 (2007) (Bol.); By 2007 sustainable tourism had become Latin America's development buzzwords, a panacea for the problems of poor and indigenous people. It is defined as combining low-impact tourism methods with the funneling of tourism money directly into local communities. This is often taken to mean that communities should self-manage sites of tourism. Community self-management at all levels is a primary focus of the Morales government.

64. The constitution was approved by popular referendum and according to Bolivia's Corte Nacional Electoral over $90 \%$ of Bolivia's voting population participated in the referendum. Slightly more than $61 \%$ of voters chose to approve the new constitution. The vote broke largely along racial lines, for example in the largely indigenous Department of Potosí, $80.07 \%$ voted to approve constitution. In the largely white Department of Santa Cruz only 34.75\% voted to approve the constitution (see Corte Nacional Electoral de Bolivia 2009).

65. BOL. CONST. (2009) preamb.

66. BOL. CONST. (2009) art. 1.

67. BOL. CONST. (2009) part III.

68. BOL. CONST. (2009) art. 1.

69. BOL. CONST. (2009) art. $5 \$ \mathrm{I}$.

70. As is freedom of "cosmovision"; BOL. CONST. (2009) art. 4.

71. BOL. CONST. (2009) art. $30 \$$ II.3.; An important symbolic move in the autonomization process. For example "Aymara" may be inscribed legally on a passport, essentially placing an individual's Aymaraness alongside their Bolivianness. 
72. BOL. CONST. (2009) art. $300 \$$ I.19.

73. BOL. CONST. (2009) art. 302 \$ I. 16 and art $302 \S$ I.31.

74. BOL. CONST. (2009) art. $304 \$$ I.10; the archaeological centers are referred to as "theirs" (the indigenous group's) at this point in the constitution. Later law seems to indicate that this is rhetorical: As the original indigenous inhabitants of Bolivia, all archaeological sites are their sites, even if the state retains ownership of all archaeological material. Archaeological centers are listed with religious sites in this section of article 304, and they are probably being treated as religious sites. However, the wording is ambiguous.

75. The debate over who owns the past and, indeed, if the past can even be owned is at the core of modern heritage management. In the eyes of most legal systems, however, the material remains of the past can be owned and in Bolivia these remains are owned by "the nation."

76. Law 031 (2010) (Bol.). The Morales administration names significant pieces of legislation after symbolic individuals. Andrés Ibáñez was a politician in Santa Cruz in the middle to late nineteenth century. He was eventually executing for fostering a short-lived revolution that pushed for an end to the system of indigenous serfdom that existed in Bolivia at the time.

77. Law 031, art. 86 (2010) (Bol.).

78. Law 031, art. $86 \$$ I.2, (2010) (Bol.).

79. Law 031, art. $86 \$$ I.4, (2010) (Bol.).

80. Law 031, art. $86 \$$ I.6, (2010) (Bol.).

81. Laws 031, art. $86 \S$ II.1 and $\S$ II.2 (2010) (Bol.); laws 031, 86. $\$$ III.1, and $\$$ III.2 (2010) (Bol.); laws 031, art. 86. $\$$ IV.1, and $\$$ IV.2 (2010) (Bol.).

82. Exactly how such oversight and intervention will take place is not discussed in this law and remains to be seen.

83. This issue is of significant concern to archaeologists and heritage professionals, especially in legal systems that grant individuals and groups complete ownership over archaeological material. For example, in the United States an individual is legally allowed to destroy most antiquities that they own.

84. This statement is based on the Multidimensional Poverty Index provided by the United Nations Development Programme (UNDP) 2010 Human Development Report.

85. A common complaint made by communities near small archaeological sites or museums, especially in the developing world, is that money is funneled to major sites with significant tourist appeal. It is not surprising that, faced with limited funds, poor countries tend to invest in show pieces. However, this leaves smaller and more remote sites unprotected from all forms of damage, including site looting, which leads to antiquities trafficking.

86. The argument can be made that these communities may not contain trained archaeological professionals and, thus, their plans may be inadequate. However, one need not be an archaeologist to create a competent management plan for a small archaeological site, and this is clearly an area for government-level oversight.

87. Law 2054 (2000) (Bol.).

88. Sammells, "Touristic Narratives."

89. From interviews conducted by Sammells, "Touristic Narratives."

90. "La UNESCO envía expertos para evaluar Tiwanaku” ["UNESCO Sends Experts to Evaluate Tiwanaku”], La Razón, 22 July 2009.

91. "Cultras despide al director de la UNAR" ["The Ministry of Culture Fires the Director of UNAR"], La Razón, 31 July 2009.

92. “Tiwanaku consigue que sus arqueólogos sean evaluados" [“Tiwanaku gets their Archaeologists Evaluated”], La Razón, 25 June 2009.

93. Law 2054 (2000) (Bol.); “Tiwanaku expulsa a excavadores” [“Tiwanaku Expels Excavators”], La Razón, 23 June 2009.

94. The reader is directed to the editorial pages of any Bolivian newspaper for the more salacious and unsubstantiated accusations surrounding this scandal.

95. "Ministerio auditará a la Unar y la Dirección de Patrimonio" ["Ministry will Audit UNAR and the Directorate of Heritage"], La Razón, 1 August 2009. Much of the blame for the situation was 
later placed on the former head of the national archaeological service, Javier Escalante Moscoso. In July of 2010, Escalante, among other individuals, was charged with criminal offenses stemming from the Tiwanaku scandal. See "Identifican a responsables de anomalías en Tiwanaku" ["Identification of those Responsible for Anomalies at Tiwanaku"], La Razón, 25 July 2010.

96. Carroll, Rory. "Makeover May Lose Bolivian Pyramid its World Heritage Site Listing," Guardian, 20 October 2009. Only two World Heritage Sites out of more than 900 have been delisted: an Oryx Sanctuary in Oman according to the wishes of the Omani government and the Dresden Elbe Valley due to the construction of a controversial bridge. The delisting of the Elbe Valley is widely perceived as a significant embarrassment for Germany. See Kate Connolly, "Bridge takes Dresden off UNESCO World Heritage List," Guardian, 25 June 2009.

97. UNESCO 34Com 7B.119; UNESCO 34Com 7B.105. This decision from goes so far as to recommend a complete moratorium on any archaeological excavation until a more competent national authority is established for Tiwanaku.

98. "La intervención en la UNAR revela la falta de 611 piezas" ["Intervention at UNAR Reveals 611 Pieces to be Missing"], La Razón, 12 June 2010.

99. "No se puede aún desembolsar fondos para restaurar Tiwanaku" ["It Isn't Possible to Dispense Funds for Restoring Tiwanaku"], El Diario, 24 May 2011.

100. Mandated, of course, by law 031 art. 86 (2010) (Bol.).

101. For example, see Mesa Gisbert, Carlos D. "Nacionalizar Tiwanaku" ["Nationalize Tiwanaku"], Los Tempos, 1 May 2011.

102. A particularly strong example of the conflation of Tiwanaku and the Morales administration is the use of the site for Morales's 2006 Apu Mallku investiture ceremony. In garb inspired by archaeological material (vestments that are now cultural property of the nation according to Ley 3874 of 2008) and standing atop Tiwanaku's main pyramid, Morales became the official leader of the Aymara people. This ceremony was performed the day before the official presidential inauguration as a way to place emphasis on the sense of indigenous authenticity that Morales has used to validate aspects of his political movement.

\section{BIBLIOGRAPHY}

Albro, Robert. "The Culture of Democracy and Bolivia’s Indigenous Moments." Critique of Anthropology 26 (2006): 387-410.

Bureau of Educational and Cultural Affairs. Canada. 〈http://exchanges.state.gov/heritage/culprop/ cafact.html $\rangle$ (n.d.) accessed 18 October 2011.

Dangl, Benjamin. The Price of Fire: Resource Wars and Social Movements in Bolivia. Oakland, CA: AK Press, 2007.

Gasparini, Graziano. "Mejor Conservar que Restaurar." Boletin del Centro del Investigaciones Historicas y Esteticas 16 (1973).

Janusek, John W. "Khonkho Wankane." Website of the Jach'a Machaca Archaeological Project. 〈http:// www.khonkhowankane.org/khonkho_5.html> (n.d.) accessed 18 October 2011.

Kohl, Benjamin. "Privatization Bolivian Style: A Cautionary Tale." International Journal of Urban and Regional Research 28 (2004): 893-908.

Kohl, Benjamin, and Linda Farthing. Impasse in Bolivia: Neoliberal Hegemony and Popular Resistance. London: Zed Books, 2006.

Mamani Condori, Carlos. "History and Prehistory in Bolivia: What About the Indians?" In Conflict and the Archaeology of Living Traditions, edited by Robert Layton, 46-49. London: Routledge, 1989. 
Ponce Sanginés, Carlos. Tiwanaku: 200 Años de Investigaciones Arqueológicos. La Paz: Producciones Cima, 1995.

Rivera Cusicanqui, Silvia. "La Antropología y Arqueología en Bolivia: Límites y Perspectivas.” América Indigena 40 (1980): 217-24.

Sammells, Clare. "Touristic Narratives and Historical Networks: Politics and Authority in Tiwanaku, Bolivia.” PhD diss., Department of Anthropology, University of Chicago, 2009.

Van Cott, Donna Lee. “From Exclusion to Inclusions: Bolivia’s 2002 Elections.” Journal of Latin American Studies 35 (2003): 751-55.

Yates, Donna. "Archaeological Practice and Political Change: Transitions and Transformations in the Use of the Past in Nationalist, Neoliberal and Indigenous Bolivia." PhD diss., Department of Archaeology, University of Cambridge, 2011. 